\title{
Frank Cyril James: The Principal Years
}

\section{by Stanley Brice Frost}

The following account of the principalship of Frank Cyril James, the term of ubich ran from 1940-1962, is hased almost entirely on the James Papers in the McGill University Archives. These papers have been fully described by Dr. Faith Wallis for the publication A Guide to the Archival Resources at McGill University, Vols. 1-3, 1985. Volume 1, pp. 10-11, lists the records of the Principal's Office 1940-1962, which are generally restricted as to access, though some items include published materials which are available elsewhere, while Volume 2, pp. 40-43, describes the deposit of private papers. In the latter entry, the headings are 'Private and Autobiographical Records, 1905-1971,' 'General, ca. 1925-1970,' 'Research, ca. 1870-1970,' 'Teaching, 1924-1959,' 'Addresses, 1939-1967,' 'Pictorial Materials, ca. 1925-1970' and 'Miscellaneous, 1900-.' There are, in addition, the original manuscript of The Grouth of Chicago Banks, and two drafts of Dr. James' account of his visit to the USSR in 1959. The extent and complexity of the papers is indicated by the fact that in total they occupy over 100 metres of shelf space. This paper was initially read to the James McGill Society in October, 1989. An earlier paper 'The Cyril James We did not Know' had given the Society an account of Dr. James' family background, his education and his remarkable career in the United States, the manner of his coming to McGill and how he found himself most unexpectedly promoted to principal. The present paper proceeds from that point and attempts to identify and assess James' major achievements during the years he held office. A biography, 'The Man in the I vory Tower: F. Cyril James of McGill has been completed and publication is expected early in 1991 .

Ce compre rendu du rectorat de Frank Cyril James, dont le mandat a duré de 1940 à 1962, est presque entièrement tiré du fonds James faisant partie des archives de l'Université McGill. Faith Wallis a donné une description complète de ces écrits dans $A$ guide to the Archival Resources at McGill University, volumes 1-3, 1985. Le premier volume pp. 10 et 11, dresse la liste des dossiers du rectorat entre 1940 et 1962. L'accès à ces dossiers est généralement restreint quoique certains contiennent des documents publiés disponibles ailleurs; le deuxième volume pp. 40 à 43, décrit la collection de ses écrits personnels. Cette dernière entrée comporte les titres suivants: "Private and Autobiographical Records, 1905-197 I", "General, ca. 19251970", "Research, ca. 1870-1970", "Teaching, 1924-1959", "Addresses, 1939-1967", "Pictorial Materials, ca. 1925-1970", et "Miscellaneous, 1900-". Elle contient en outre le manuscrit original de The Growth of Chicago Banks, et deux versions du récit de James sur sa visite en U.R.S.S. en 1959. L'étendue et la complexité de ces écrits sont attestées par le fait qu'ils occupent plus de 100 mètres de rayonnage. Cette communication a été présentée à l'origine devant la Société James McGill en octobre 1989. Un autre document intitulé "The Cyril Janes We did not Know" avait permis à la Société de se faire une idée des antécédents familiaux de Cyril James, de son éducation, de sa remarquable carrière aux États-Unis, de son arrivée à McGill et sa nomination très inattendue au poste de principal. C'est le point de départ du présent écrit dont l'objet est de définir et d'évaluer les plus grandes réalisations de James durant son mandat. Il existe maintenant une biographie intitulée "The Man in the Itory Tower: F. Cyril James of McGill" qui devrait être publiée en 1991. 
Frank Cyril James The Principal Years

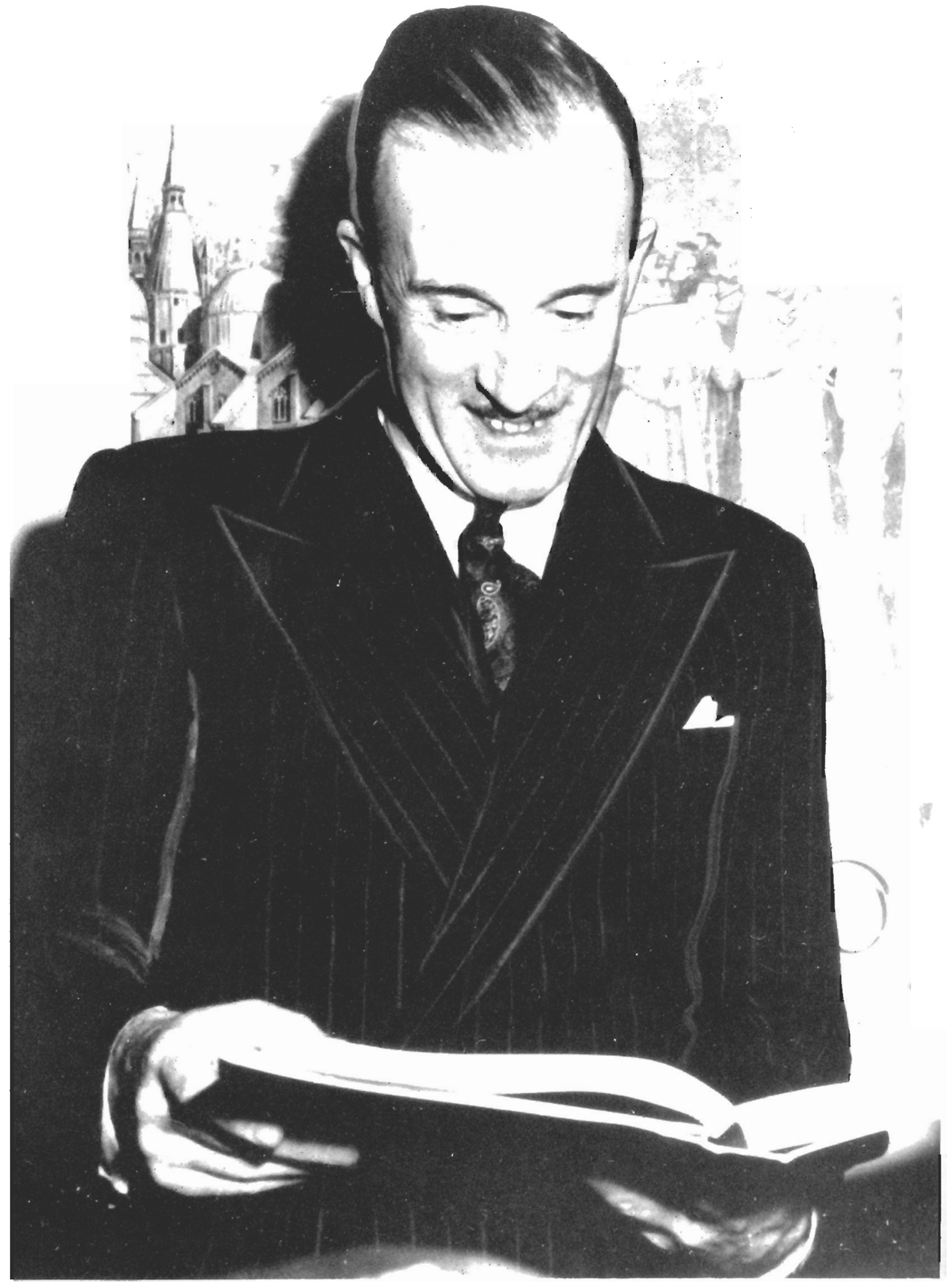

F. Cyril James, 1952. (McGill University Archives.) 
$\mathrm{F}$ rank Cyril James and his wife Irene arrived in Montreal in 1939 one day after war had been declared between Great Britain and Adolf Hitler's Germany. He had been inveigled rather unwillingly to come to Montreal for two years to reform the McGill School of Commerce, which at that time, was in a very poor condition. The Principal of the University, Lewis Douglas, was an American, brought in by Chancellor Sir Edward Beatty to revive the somewhat tarnished reputation of McGill generally, to counteract some vague socialistic tendencies amongst students and junior staff, and particularly to bolster up the sagging financial fortunes of the private enterprise university. The Great Depression still had the country, indeed the world, in its grip, and McGill at this time, it has to be remembered, still relied on student fees, income from investments, and donations from wealthy benefactors. The university had practically no access to government funds.

Douglas had persuaded James to come to McGill as part of his program to reinvigorate the university. But war had broken out, and now the American principal wanted to return to his own country, which at that time was officially neutral. Within a month Frank Cyril James found himself Principal-Designate of McGill, and was expected to assume his new responsibilities on 1 January 1940 . But events continued to move at breakneck speed. Lew is Douglas had planned to leave Montreal at the end of November on a visit to the West Coast, and announced that he would not be returning to McGill after that visit; he was in fact departing for good. James was therefore appointed Acting Principal as from I December 1939. Sir Edward Beatty, who had been largely responsible for the direction of the University since Sir Arthur Currie's illness and death, was himself taken seriously ill on 17th December, and early in January left the hospital and city for a long convalescence in the States. The new young principal found himself alone, in a university he did not know, in a country he did not know, and a wartime situation which neither he nor anyone else could foresee or plan for. He was thirty-six years old, and had never held executive office.
Bereft of mentors, Cyril James was alone in another more fundamental sense. His wife Irene had never been much in love with Philadelphia or the United States, having never severed her affections from England, but she quickly took a positive dislike to Montreal and Canada and especially to Cyril's new position. In those days, the Principal was indeed a man apart, as much as any captain on a ship; he was not expected to form close friendships with members of the staff, and his wife was not expected to consort with other faculty wives; her social relationships were expected to be contained within Montreal's upper crust 'square mile,' the social set of the city's merchant princes. These were people with whom Irene had nothing in conmon and whose background of wealth and education she did not share. Even in October 1939, while James was still Principal Designate, he was lunching everyday with deans and departmental chairmen, and most nights he was attending evening functions of the University or the Graduate Society, or Cyril and Irene would be invited to dinner with one or other of the Governors, and these were formal social occasions which Irene found increasingly hard to take.

A month later in January 1940 James was writing in his diary about a visit back to Philadelphia:

Irene, who came down to spend the weekend with me, is not at all pleased by the prospect of all that the new job entails and has also fallen for Nina's brother in New York, so that she was none too sure that she wanted to come back to Montreal at all. In the end, I persuaded her to come back with me, but I do not think that she is particularly happy here and there is no question at all that she is very worried and highly nervous... I suppose that we shall find some way to straighten things out-but it is going to be an aw fully hard job to arouse any enthusiasm in Irene, and hard still to get her to enjoy life. I am in the position of needing to think out the problems of home almost as 
much as those that arise out of the office, and have more than a suspicion that between the two I shall make a very bad botch of the whole thing.

His hope that 'we shall find some way to straighten things out' was not going to be fulfilled that first year. In April 1940 he wrote:

\begin{abstract}
These latter days have brought a feeling of weariness and disillusionment that I find hard to fight off... For many years I have been an individualist, making few close friends and not leaning on Irene at all. I was proud of my independence, proud of the fact that I could run my own life. False pride discovers its nemesis and I find life desperately lonely now that Irene is far away, spiritually as well as physically, and there is nobody else at hand.
\end{abstract}

Irene continued to take long holidays in New York, as later she was to spend long summers in England. Left to himself, by the beginning of May, there is little doubt that Cyril James was tottering on the verge of a nervous breakdown. Here is a diary note for 5 May:

Dr. Walter Chipman a member of the Board of Governors gave a very pleasant lunch today, and I spent most of the afternoon with Sir Edward who sets out tonight for his [recuperative] holiday. Both of them, in different contexts, said very nice things about me and the work that I have done-but I must confess that I feel unworthy of the compliments. For several days now I have done nothing but potter, without being able to put my mind to anything. Perhaps the psychologists would say that I had a bad case of nymphomania and, if any of them could read and publish my thoughts, I should certainly be kicked out of Montreal. Everything that wanders through my mind centers around women, and they are not soft sentimental thoughts, but somehow in the scramble of the years that brought me here I seem to have lost the art of making love either to Irene or to anybody else-so I just go on thinking fiendish thoughts that harm nobody but myself.

It is against that background that James achivement in this first year has to be measured. He was formally installed as Principal in the Moyse Hall on 12 January. At that installation he likened the ceremony to the initiation of a young man to knighthood, or to the swearing of the oath of fealty: after the ceremony of installation, in his acceptance speech he said: "This Installation Ceremony may be regarded as a descendant of those solemn occasions when men swore fealty, and in like manner, I wish now, publicly, to dedicate myself to the service of McGill. I am resolved that such talents as I have shall be devoted to the University, in the hope that its progress in the years that lie ahead of us may be a worthy continuation of the great story of its past."

Amid the rustle of academic gowns and the soft cadences of Hail, Alma Mater that may have sounded a little histrionic or perhaps forgivably romantic; but Cyril James meant those words, in all seriousness, and his life for the next twenty years was to be lived in faithfulness to that vow. It was a splendid dedication; but it did not make life any easier for poor Irene, and although they never separated, relationships between them never improved. During his working life, Irene was never able to give Cyril James more than minimal support or companionship. After he retired, as far as I can judge, she became a burden which he had to carry, and when he was taken from her by the final heart attack, she also collapsed and died some ten days later. It was indeed a tragic story, for both of them. Cyril James deserved a better partner for his life of dedication and single-minded career, Irene deserved more understanding and a much lesser challenge.

But that private tragedy was known to no one expect the participants-at least, not here in Montreal. Irene's absences were noted, and politely overlooked; Cyril James for his part 
was not the man to utter or to invite confidences. In his public life, he gave the impression of competence, energy, quick decision, immense knowledge, and infallible judgment. The only place where he fell down occasionally was in his judgment of persons. He gave tremendous care and thought to appointments in all departments throughout the whole university; generally he followed sound advice and his choices were good. But once or twice both his advisors and his own judgment failed him with disastrous results. In the middle fifties, for example, he went to England and met a distinguished organist. He was so impressed that he engaged him then and there as Dean of Music at McGill; he came back to Canada to find that the whole faculty of music had resigned en masse, chanting fortissimo 'We will not have this man to reign over us!' James had to pay the English organist a year's salary not to come to Montreal. Great men have great faults, and nearly all of James' pratfalls were in the area of personal relationships.

When he was not preoccupied, James could be thoughtful, generous and kindly, as a great many McGill recipients of condolence messages, get-well cards or discretionary grants in time of trouble, could testify. The one who knew him best was Dorothy MacMurray his secretary for twenty years. She characterizes him in her book Four Principals of McGill as a tireless worker, utterly devoted to the wellbeing of the university, and (when he was not absorbed in some scheme or plan for its improvement) capable of many kindly and generous actions. She wrote 'Those who were privileged to see his other side know that he was in fact a very warm and a very human person ... He was not really of a cold temperament, as friends found out, but he did often give the impression of being uncommunicative and withdrawn.' At such times, he could be guilty of major social gaffes-as when, for example, he came into the office unexpectedly one Sunday morning and found Mrs. MacMurray cleaning out her desk. When he expressed surprise, she had to remind him that she had retired the previous day and after thirty-three years as secretary to four principals. James confided the story of his blunder to his diary with a large exclamation mark. He knew his own faults. He certainly was a com- plex personality - but of his intellectual brilliance and his strength of purpose, there can be no doubt.

\section{His first task was to learn McGill} University, and learn it he did. With each of the deans he went through the academic budget line by line, name by name; with the University Librarian, the Director of Physical Plant, the Superintendent of Building Services, he did the same; he followed the same pattern with the heads of the adminstrative services and all their counterparts at Macdonald College. By the time he came to prepare his first university budget he knew the university in detail better than any other person on campus. Then there were all the other, more unusual items to be coped with. A glance at the twelve closely typed pages which were his personal notes for a meeting of the Executive Committee of the Board of Governors gives us some idea of the complexity of the matters he dealt with on that one afternoon. The Agenda dealt first with the Principal's Report, covering such matters as the University's tax exemption, and the Macdonald College Bill, currently before the Provincial Assembly. The Agenda then goes on to deal inter alia with negotiations with the Morgan family relating to McGill's possible acquisition of the Morgan Woods and Farms; necessary changes in the management of both the Royal Victoria College and Douglas Hall; the possibility of McGill taking over the Lachine Rowing Club; the rather vaguer possibility that McGill might set up a School of Marine Engineering and Naval Architecture; a list of persons to receive honorary degrees; a list of academic appointments and reappointments; increases in the board and lodging fees at Macdonald College, with provision for much needed bursaries for the poorer students; the sale of Westmount Mountain Summit to the City of Westmount; the report of the Real Estate Investment Committee, concerning the purchase of houses on University Street; a scheme to cooperate with the Ayerst McKenna and Harrison Company in the manufacture of bacteriological products in great demand by the Government; revised financial estimates for the University's operation in 1940-41; a forecast of the financial situation 
for 1941-42; and a list of Gifts, Grants and Bequests.

As if that were not enough, under item 15, "Other Business," several further items were raised, largely as matters of information, but one was particularly significant: someone had had the temerity to nominate a woman for election by the Graduates to the Board! Fortunately the Principal had been equal to the occasion. As he informed the Board, not only had he encouraged "private pressure by the Graduates' Society on the branches" for the election of $\mathrm{Mr}$. Hugh Crombie, but he would also suggest to the Society constitutional amendments to ensure that in future such proposals could be eliminated at an earlier stage. So much for "Women's Rights!"

In the absence of the Chancellor, James as Vice-Chancellor took the chair at the meeting and he guided the Board with masterly competence through the whole complicated maze of business, knowing what he wanted and making sure that the members of the Board were left satisfied that what they had concluded was also what they wanted. Those who saw James in action in such a setting were always immensely impressed; as one governor once remarked: "It was difficult ever to disagree with James; he always knew all the facts."

What then were the main achievements of Cyril James during his twenty two years at McGill? The answer is best summarized, I think, under three heads: coping with university expansion, the business of Federal grants for universities, and putting McGill on the world map.

\section{COPING WITH EXPANSION}

James had to provide for an immense enlargement of McGill not once but twice during his principalship. When he came to Montreal in 1939, the University had an enrollment of 3,275. But only a year or two into the war, James realized that the end of hostilities would bring a large increase. The wartime cabinet of William Mackenzie King has promised university bursaries to National Service veterans who could benefit from them. Once the war ended, these men and women would come knocking on McGill's doors. How were they to be accommodated, who would teach them, how could lecture rooms, laboratories, books and supplies be provided? McGill's financial resources were already strained to the uttermost. How could the university cope if the student body were to be doubled?

One problem was that many of the academic staff remaining at McGill had heard of the war only from afar. They were very slow to respond to the urgent warnings of the young Principal, who was still very much a stranger if not an interloper among them. His relations with the staff were still very strained and formal. Elsewhere, however, he found sympathetic and quick understanding. He took his financial concerns to a member of the Board of Governors who was beginning to fill the gap created by the passing of Sir Edward Beatty. John Wilson McConnell was a very successful businessman of little formal education but great imagination and percipience. He understood James' problem, and privately, among his friends and business associates he raised over $\$ 7$ million to enable the university to respond to the challenge of postwar expansion. At that time, that was a very large sum of money. James also went to his colleagues at the National Conference of Canadian Universities (NCCU) and persuaded them to ask the Federal Government for help. It was not enough, he argued, for the Government to give bursaries to veteran students: the institutions which were to receive them must also be given per capitum grants to enable them to provide the teachers, the lecture rooms, the laboratories, the libraries, which they would need. The Government fortunately agreed and with these two sources of funding assured to him, James was ready to receive the vets. The first class enrolled in January 1945; many were still in uniform, and James met them ceremonially on the Arts Building steps. But more arrived in May, a Summer Session was organized, by September the numbers were overwhelming. The enrollment of $3,275 \mathrm{had}$ grown to 6,370 , and increase of almost $100 \%$-and still more were yet to come.

James decided on 5 September that the only answer was to find a subsidiary campus where 


\section{Frank Cyril James The Principal Years}

"instant college" could be conjured up out of (as it then seemed) thin air. He turned to the Government's War Assets Corporation, and secured the use of a disused RCAF Training School at St. John's on the Richelieu. With the help of Douglas Abbott, a McGill graduate, who was then Minister of Defense, he obtained the buildings of the school, including dormitories, kitchens, lecture room, laboratories, and from the Minister of Ordinance he secured supplies from Army depots in Montreal, Ottawa, and Toronto. Beds, sheets, blankets, cutlery, kitchen utensils, tables, chairs, bunsen burners, chemical supplies, a library (from McGill) came pouring in. The new administration of Sir William Dawson College moved in on 27 September and the first meal was served that night in the dining hall. Finding teachers was more difficult, but it was done. Classes began the following Monday, the first day of October, twenty six days after the idea had been mooted.

Dawson College, as we all know, went on to be an immense success. Almost as importantly, it forged a new relationship between the young principal and his academic colleagues. Previously they had responded sluggishly to his warnings of a crisis to come. Now that they could see the problem for themselves, and having a large share in the solution of it, they worked enthusiastically under the leadership of one who was boldly imaginative, superbly efficient and apparently tireless.

The second time that McGill coped with expansion came ten years later in 1955. At the NCCU meeting that year, E. F. Sheffield read a paper on "Canadian University and College Enrolment." He showed with statistics and graphs that the postwar "baby boom" would hit the universities over the next decade. Already, an increasing percentage of collegeage young men and women were seeking university education, and the size of the group and the percentage choosing university would continue to increase until by 1965 their numbers in Canada as a whole would have doubled. Cyril James saw that McGill was once again facing an immense expansion.

But this time around conditions had changed. No longer was he alone, seeking to prod a reluctant staff into awareness of the sit- uation. The McGill Assocation of University Teachers had been formed and were pressing for a larger role in university administration. Departments and faculties were brimming with ideas for new courses, new teaching methods, new premises, new disciplines. James' task this time was to provide the means. Where was the new money to come from? The size of the sums required were far in excess of anything university budgets had ever previously provided. McGill not only needed to be enlarged; it needed to be rehabilitated and rebuilt. The first estimates were in the neighbourhood of $\$ 40$ million; before the major tasks were completed, in the middle seventies, long after Cyril James had departed, the total expenditures were of the order of $\$ 150$ million.

James was not altogether unprepared for this crisis. After McConnell's magnificent effort to raise new endowment funds in 1944 , James went back to the Board in 1948 and persuaded them to launch what was called "McGill's first public financial campaign," under the chairmanship of another of the Governors, G. Blair Gordon, and raised a further $\$ 8$ million. But in 1956 he moved again and encouraged the Board to appoint another governor, Raymond Edwin Powell, President of Alcan, to head a further campaign, especially for rebuilding and rehabilitation. This time the total raised was $\$ 9$ million. In those days there was no McGill Advancement Program office; all the records were handled in the Principal's Office, a great deal in Cyril James handwriting and the rest hammered out on Mrs. Mac's manual typewriter. There was also another windfall waiting for McGill of nearly $\$ 6$ million which we will talk about a little later. So James was not altogether unprepared for this new challenge: but $\$ 100$ million or even $\$ 40$ million appeared to be way out of sight.

Significantly, however, a Senate Physical Development Committee was established and Cyril James was not its chairman. With James' full approval, a professor in the Department of Chemistry, Professor Carl Winkler, was appointed to chair the committee. Other prominent members were Harold SpenceSales of the School of Architecture, Kenneth 
Hare of Geography and Donald Mordell, Dean of Engineering. All these were signs of the times. No longer was James sitting alone in his office, planning far into the night; many others were being drawn into the process. The financial side was the concern of the Principal's Executive Assistant, George Grimson and his remarkably efficient secretary, Dorothy Asch. John Holton, Secretary to the Board of Governors, watched over the receipt and acknowledgement of all donations. A new team spirit was developing at McGill, and James was very ready to encourage this, though he still guarded his prerogatives as Principal very carefully. All operating expenditures had to be sanctioned by him, and all salary increases, promotions or academic leaves of absence depended on his decision. Whether a dean went into his office with a request for a new typewriter or the promotion of a typist to secretary, or the promotion of an assistant professor to the associate rank, the answer, given then and there, was either yes or no. Life was simpler in those days; and on the whole, I think, justice was done. James was a superb administrator because he had full executive powers, he had a very detailed knowledge of all the departments, and he had no personal axes to grind. People have complained that he was a cold fish-but it also meant that he had few if any prejudices, and he had no particular favorites. The well-being of the university was his overriding concern. But there was still that major question where was the money for this second major expansion to come from?

\section{FEDERAL GRANTS}

So we come to the second area of James' major achievements, the securing of Federal Government grants, not only for McGill but for all Canadian universities.

We have seen how when the veterans came flocking into the universities after World War II, James and his colleagues at the NCCU secured federal government grants not only in the form of bursaries for students, but also grants so much per veteran student for the institutions to help them meet the additional costs.
But the time came in the early fifties when the vets began to graduate, and as they departed, these federal grants departed with them. But the expenses remained: buildings to be operated, additional staff to be paid, equipment to be maintained, new disciplines to be financed. Nor were the student places left empty. As we have been reminded, the war had stirred up the whole Canadian population, and more young men and women were choosing university level education. Their fees only paid about one-third of the cost of the services they received. McGill of course was not the only institution to suffer. Most other Canadian universities were in receipt of provincial grants, but as the veterans departed, those provincial grants fell far short of making good the loss of the federal money. In McGill's case, to make matters worse, the university did not receive provincial grants. How was the situation to be resolved? Cyril James was elected president of the NCCU for the years 1948-50. He used the opportunity to persuade his colleagues that they must approach the Federal Government again. The coming need, he said, was so great and urgent that only the federal purse was deep enough to provide a resource. Accordingly he led a delegation to interview Prime Minister Louis St. Laurent. The Prime Minister was flanked by his Minister of Finance, the same McGill graduate Douglas Abbott whom we met earlier. St. Laurent was sympathetic but, he said, governments could only support causes which the population at large supports. James and his colleagues must go out and sell to the Canadian public the idea, that the federal government should give grants to Canadian universities. James responded with alacrity. He had university presidents preaching the idea all over Canada, at convocations, at Canadian Club or Rotary, Lions and similar lunches, in articles written for magazines and newspapers. They also made their pitch to the Royal Commission on the Support of the Arts, Letters and Sciences in Canada, the so-called Massey Commission, which St. Laurent had already set up. The Commission submitted its report in late 1950 , and recommended direct grants to the universities based on the student population in each degree-granting institution. This recommen- 
dation the government, largely as a result of the NCCU campaign, accepted for immediate implementation and so in 1951-52 McGill received a statutory government grant for the first time. It amounted to $\$ 615,270$ or about $10 \%$ of the total operating budget. It would be used, James explained to a jubilant staffassembly, for much-needed increases in salaries, not only for academic ranks but also for non-academic staff members. The announcement of that government decision was the occasion of a day of rejoicing; a new era had begun for all universities, and especially for McGill.

But then trouble erupted. James had argued that the Federal Government had a supervisory right to enter the field of education directly, but not everyone was ready to agree. Marcel Faribault, Secretary-General of the University of Montreal, wrote to the NCCU denying it had any legal right to represent all universities and that the federal government had no right to fund universities, since education was a field reserved for provincial jurisdiction. That brought Maurice Duplessis, the nationalist premier of Quebec, into the fray. He forbade Quebec universities to take the federal funds. The funds for the Quebec universities had to be put aside by the federal authorities into a separate account "until such time as the Quebec institutions are able to receive them." This was a very trying time for Cyril James. McGill was desperate for money. He had secured federal funds for all Canadian universities; in particular, McGill's main rivals, Toronto and U.B.C., were receiving them freely. Yet McGill, faced with increasing enrollments and rising costs was forbidden to accept them.

Matters dragged on unhappily until 1956. Up to this point, the practice followed had been that universities had to apply to the federal government, which duly handed over the appropriate amount. Now the government tried a different approach. All the money would be given in one lump sum to the NCCU, and they would distribute it according to the proper norms. The university would not have to apply, the cheque would not come directly from the federal government, but would simply arrive in the mail from the
NCCU. Duplessis responded by letting it be known that the governors of any Quebec institution accepting the cheque could expect retributory taxes to be slapped on their enterprises. Newsprint was specifically mentioned. This measure was particularly aimed at the owner of The Montreal Star, J. W. McConnell, McGill's greatest benefactor, and James' particular patron and advocate.

James personal position was now very difficult. The McGill Association of University Teachers, led by F. S. Howes, James Mallory and Maxwell Cohen, were pressing McGill to accept the cheque, now amounting annually to $\$ 1,189,00$ or about $16 \%$ of the total academic operating budget. When the debate was carried on in Senate, James had to preserve the appearance of neutrality, in order to be loyal to McConnell and the Board; but in the privacy of the Board meeting he strongly urged acceptance of the cheque and defiance of Duplessis.

James confided his unhappiness to his diary:

The arguments within the University on the subject of University grants have been bitter. I have shown to the Board of Governors my strong personal feeling that McGill should accept them-and as a result have lost the confidence of McConnell (who is angry) and some of the other senior governors. With the academic staff I have felt that I should be neutralsince I cannot side openly with them against the Board-and some of them feel I have not been enthusiastic enough about the idealist independence of the University. On both sides I have lost out...

The Board of Governors decided to return the cheque and James had the unhappy task of informing the professors that the longsought salary increases must be further delayed. As H. H. Walsh, a theology professor, expressed it, McGill was left with the cold consolation: "While there's death, there's hope." 
But two years later that hope did indeed prove well-founded. In September 1959, while visiting Northern Quebec, Maurice Duplessis died suddenly of a heart attack. His successor, Jean Sauvé, hastened to come to an accommodation with the new Prime Minister, George Diefenbaker and the federal funds were released to Quebec universities. This not only brought McGill a fresh source of income, but it also meant that from now on McGill would be eligible for all government funds, federal or provincial, just like the other universities, - une université toute comme les autres. It was the beginning of a new era for McGill. It also meant that the nearly $\$ 6$ million which had accumulated since 1953, when the Duplessis interdiction began, could now be released to the university and could serve as the beginning of the capital fund out of which the rehabilitation and reconstruction could be financed.

Beyond all the minor and major achievements of his twenty-two years of principalship, the securing of federal funding for the universities of Canada, is Cyril James greatest and most enduring success. The government grant to McGill is now about $80 \%$ of the academic operating budget; it comes by way of the Provincial Government, but its source is still the federal government, and that is true for all universities. As James saw so clearly, Canada is one country and can have only one education policy for all its citizens, whether they live in rich provinces or poor ones. Canadian students must be able to move freely from one province to another and attend the university of their choice. That is a privilege we must seek jealously to conserve.

\section{PUTTING MCGILL ON THE WORLD MAP}

Cyril James' third major contribution, renewing McGill's place on the postwar world map, was one not so easily visible to the community on campus, for it concerned his activities in the wider world beyond, but it proved extremely important. The first area of influence was the National Conference of Canadian Universities. Before the war this had simply been a meeting place where presidents and their senior staff could exchange ideas. The war situation, however, required that the
Conference should be able to speak for the universities in negotiations with the Government, on such matters, for example, as exemptions of staff and students from the call-up to National Service. James proposed in 1940 that the NCCU should name a small committee to negotiate on the universities' behalf. When the committee met for the first time to speak with the Minister of National Defence and his senior officials, President Henry Cody of Toronto, the current president of the NCCU, asked James, although the youngest and least experienced member of the committee, to be their spokesman. James had done his homework, and quickly shewed that he knew a great deal about the National Service Act and the range of possible exemptions. From that time on, and especially in the campaign to obtain federal grants for universities, Cyril James was a leading member of the NCCU, and McGill's voice was always clearly heard in all the Conference's deliberations. There were three or four leading academic figures who were at that time know nationally across the country: Sidney Smith of Manitoba and later of Toronto, R. C. Wallace of Queen's, Norman Mackenzie of New Brunswick and later of U.B.C. and Cyril James of McGill. They dominated the NCCU in the 1940s and 1950s; James was the new boy in the war years, but he went directly to a position of leadership, and he outlasted all his peers, so that over the years he added longevity to his other qualities. By the middle fifties, there were few attending the NCCU who could remember a time when Cyril James was not a strong and constant influence in its councils. In this way, the role James played in the Conference greatly enhanced McGill's reputation across Canada.

The second area was more remote but came to be extremely important. James visited Britain twice in wartime and each time he made a point of establishing relationships with academic leaders-in London, Oxford, Cambridge, Glasgow, Birmingham, Bristol. When the war ended, he was active in reviving the Association of Universities of the British Commonwealth ( $A U B C$ ). He was elected Chairman of its Executive Committee, and persuaded that body to meet outside Britain for the first time in Deep Cove, Nova 
Scotia, in the beautiful home of Cyrus Eaton, the American tycoon and philanthropist. As Chairman of the AUBC Executive, James visited the Caribbean, India, Pakistan, Australia and New Zealand and nurtured his contacts there. As a result, he was able to propose that the 1958 Congress should meet (also for the first time outside Britain) in Canada, at McGill, which it duly did as some of us well remember. That Congress was an immense success, with the Americans as much as with the Commonwealth, for members of the American Association of Universities, of which McGill and Toronto are full members, were invited to join in the Congress, and they responded by inviting the Executive Heads of institutions to travel by special train to Washington to take tea with the President. All of these activities greatly enhanced McGill's worldwide reputation.

Another of James activities was with the International Association of Universities (IAU). As he said, with the American Association and the Canadian Conference providing for North America, and the AUBC covering the British Commonwealth, the International Association provided the same services for the rest of the world. He served assiduously on its Executive Council and for two years acted as its chairman. He also went off to the USSR in 1959 and spent nearly two months studying Soviet education and institutions. It was not surprising then that when the International Association met in Mexico City in 1960, for the third quinquennial Congress, the man they elected as their president for 1960-65 was Frank Cyril James of McGill.

There is a story that when McGill invited Viscount Montgomery, the World War II General, to Montreal to receive an honorary degree, the reporters at the dock asked him if he was going to visit any other universities while in Canada. He replied 'A re there any other universities in Canada?' The story may be apocryphal, but it testifies to the way in which Cyril James had strengthened and renewed McGill's world-wide reputation. Institutions that are known and respected attract more students than those that are not so well-known, more research funds, more bequests and donations, more amibitious sci- entists and more outstanding scholars than those that are not well-known. The Book of Proverbs says: 'A good name is to be chosen rather than great riches.' James saw to it that McGill had that good name world wide as well as its due share of the world's riches also! He was indeed a very able Principal.

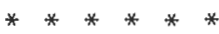

But he was also as we said earlier a very complex character. His unhelpful home life tended to increase his own quirks of character, and few if any of his colleagues knew him at all intimately. In 1957 Bertie Gardner retired as Chancellor and the Board elected in his place the governor whom we have already mentioned, Raymond Edwin Powell, known to his associates as Rip Powell-the name is a combination of his initials and his reputation as an astute, able but ruthless president of Alcan. He and James did not take to one another; they were in some ways too alike. Powell quickly became critical of James. He thought James spent too much time on his extra-curricular activities. Actually, as James had little home life, no hobbies other than a little gardening and a fair amount of reading, he spent practically all his working hours on university work of one kind or another. His travels were his form of vacation. Sidney Dobell, his Executive Assistant for nearly eight years, said that he was an extraordinarily fast worker: 'there can be no doubt,' he wrote, 'that Cyril James did the work, not merely of one average man but of two or even three.' Powell was wrong to think that James neglected McGill for his wider activities, but there is no doubt that his interest in the university was beginning to flag a little. By 1961, he had done this job for more than twenty years. He had more than fulfilled that vow he made in Moyse Hall to devote all his energies to this task to which he had been called. He began to flirt with the idea that perhaps in a year or two, it would be time to think of retiring. Somewhat incautiously, in December 1961 he asked the Board of Governors to appoint a small committee to look into the question of what pension he might expect if and when he should retire. Powell saw his 
opportunity. He used the committee to produce an answer, not merely as to what the pension would be if James were to retire, but that he should indeed retire forthwith, and that such and such would be his pension. 'If I correctly interpret the views of the Governors he wrote to James on 24 February 1962, 'they would like to have the resignation presented to them at the next meeting, now scheduled for 16 April.' Actually, there was another meeting hurriedly called for 20 March, at which the James resignarion was presented and accepted. The March vote was confirmed at the April meeting, but most governors were still left thinking the initiative had come from James. Rip Powell had engineered a coup d'état without most people even realizing it had been effected. But no public announcement was made.

James called a staff meeting in the Moyse Hall two days later. At that meering he went over the great improvement which had been achieved in McGill salaries and working conditions since the coming of federal funds into the budget, and expressed the confidence that this progress could be maintained for the future. He also pointed to the great improvement and extension of the physical fabric of the university in the last few years and the existence of the new master plan to provide for the increased numbers of students, the increased staff to teach them, and the increased facilities that they would require. He then added:

In summary then what I am trying to convey to you is a program of planning which has taken shape much more quickly, much more clearly, and much more useful for the university than I anticipated last year-a program in which a substantial number of members of the university are involved and one which I am confident is going to be carried out.

Everyone present realized that this was an historic moment; the university had achieved under Cyril James' leadership unparalleled accomplishments. Now he was pointing them forward to even greater heights, and instilling a strong confidence that those goals could and would be reached. It was then that he added:

As a last statement today I want to tell you that in view of these developments and of the smoothness with which they are moving forward, I have been discussing with the Board of Governors the appropriate time at which I should vacate my present office and let a younger person come in and carry these plans through to completion. As a result of all the discussions over the last two weeks I shall be vacating that office somewhere around the end of this calendar year; as soon as a successor is appointed.

There were to be many more public appearances, but they were in the nature of curtaincalls - the last dramatic scene of Cyril James' principalship was played out on the Moyse Hall stage on 18 April 1962. The role accepted on that same stage at his installation on 12 January 1940, had been played for twenty-two years with mounting success and authority, and now he had crowned his performance with a dazzling display of targets achieved and successes to come. He had also provided himself with an unbeatable exit-line.

But where was he going to exit to? Irene persuaded him to retire with her to England. He was given a tremendous send-off by the whole McGill community; expressions of admiration, gratitude, and even affection were showered upon him. He was named Principal Emeritus. But his life's vocation had been taken away from him. After he finished his largely ceremonial term of office as president of the International Association of Universities in 1965, he slipped gently into a quiet obscurity. Perhaps it was the right thing to happen; he had achieved mightily in the United States and in Canada for forty years; by 1962 , not yet sixty years of age, he was already burned out. But in the years of war, and in the critical postwar years, and in the twenty-two years of his principalship, he laid out the plans and founded the resources with which we are still building today. 